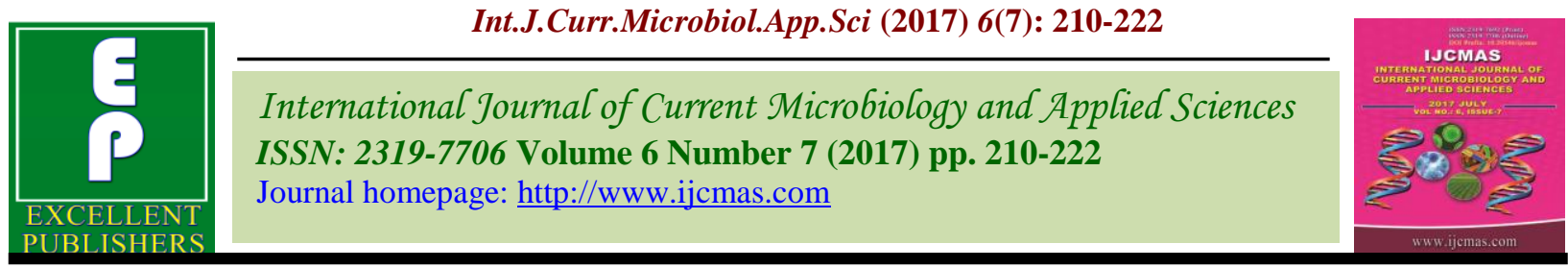

Review Article

https://doi.org/10.20546/ijcmas.2017.607.025

\title{
Agroforestry: Viable and Futuristic Option for Food Security and Sustainability in India
}

\author{
Yogesh Kumar and Tarun Kumar Thakur* \\ Department of Environmental Science, Indira Gandhi National Tribal University (IGNTU), \\ Amarkantak, Madhya Pradesh, India \\ *Corresponding author
}

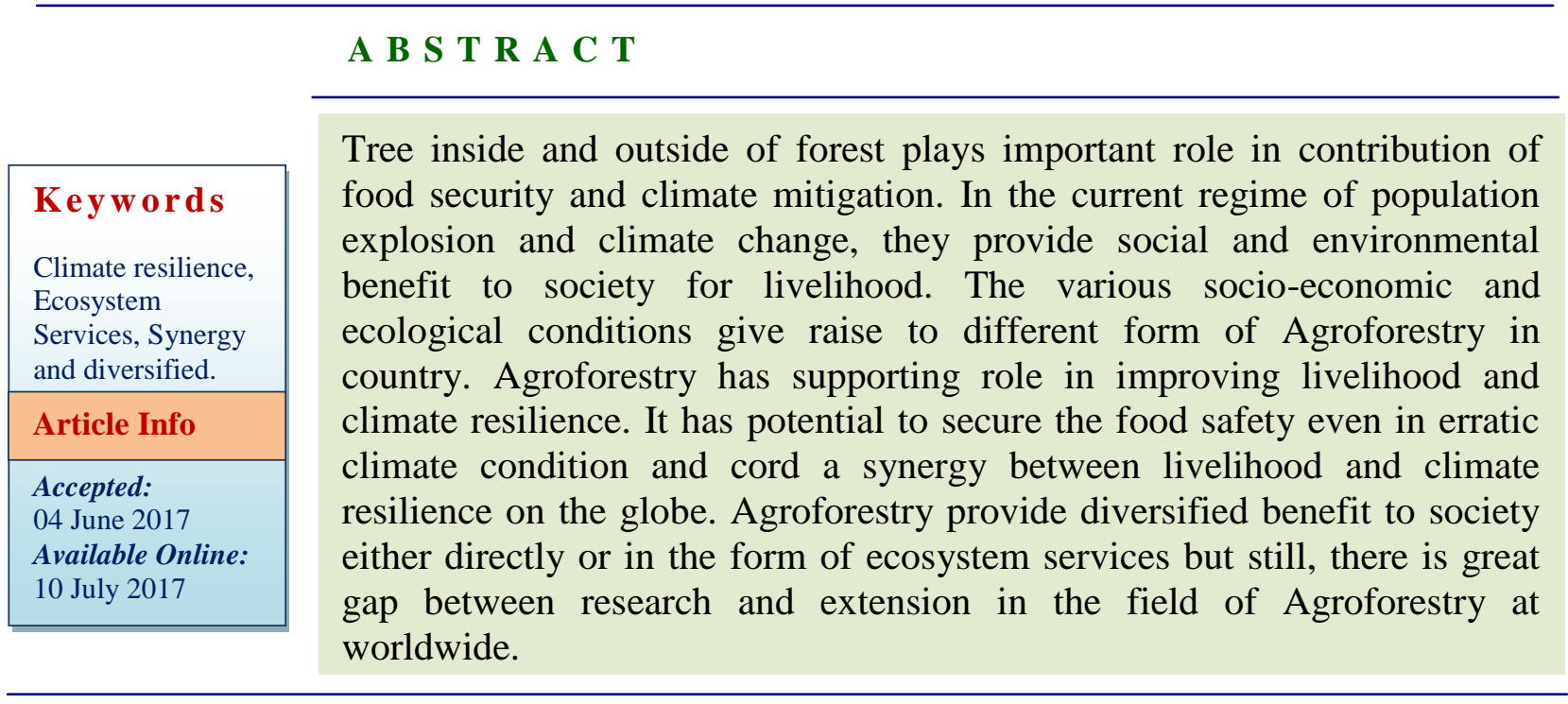

\section{Introduction}

Subject of food security is a big question mark to humankind, meanwhile the food security depend on nature, consequently nature and food are interlinked with each other. In the meantime developing countries like India, where population grows exponentially and pressure on natural resources is soaring, facing problems at great extent. However the food production of country increased many time in recent years but simultaneously, population and climate variability also increased many fold.
More than $75 \%$ population of India depends on agriculture for survival and income (Thenmozhi et al., 2014). Agriculture of India fully dependent on mansoon, so there is very less possibility to supply regular food per person in country in current regime of climate variability. At present there is a vast tract of land present in country which is not suitable for cultivation of agriculture crops due to land degradation, salt affected soil, shallow soil condition and biotic interference. Widespread concerns of climate variability, land 
degradation, soil condition, biotic pressure and food insecurity in country, Agroforestry show the viable option for food security and climate resilience for present and future prospective. Agroforestry is a sustainable and multiple land utilization system in which trees incorporates with crops and/or livestock on same unit of land at a time. Many small, marginal and big land holder practices Agroforestry from ancient time in India but scanty information available on these practices though some author made attempt to consolidate the information on their publications (Dhyani et al., 2011; Kareemulla et al., 2009). They explain different type of Agroforestry practices prevalent in India during Vedic Era, Epic Era and Medieval period in there text. It was not new that society obtains benefit from Agroforestry either directly or in the form of ecosystem services. The tree in Agroforestry system provide fuel wood, fodder, fruits and fibers to the rural community up to a larger extent in a way to improve the living conditions of the people through livelihood support and alleviating poverty (Bijalwan et al., 2013). One could easily understand that Agroforestry cords a synergy between livelihood and climate resilience on the globe. Agroforestry systems have potential for improvement in livelihoods through simultaneous production of food, fodder and firewood as well as mitigation of the impact of climate change (Panday, 2007; DeFries et al., 2010). In the current context, resources related to environment stability and to food safety are the main stirring factors in Agroforestry acceptance. Agroforestry has also encouraging functions, like improvement of soil fertility by adding organic manure through leaves, twigs and litter fall, recycling of nutrient through tree component from deeper layer to upper layer of soil (Das et al., 2008). Tree component in Agroforestry also improve moisture regime of soil by reducing interception losses, excess run-off and by increasing infiltration/ recharge rate. Tree has potential not only to arrest fast depletion of ground water table but also to reverse the trend in raising (Sahu et al., 2015). Tree component in Agroforestry sequester aboveground and belowground carbon and thus contribute in mitigation of climate change in the long run (Palm et al., 2004; Haile et al., 2008; Nair et al., 2009). Agroforestry is not only the means of growing crops with tree component and or livestock but also source of renewable energy and environment stability. In the light of food shortage, climate change and increased demand of fuel wood, timber, fodder, Agroforestry recently experience the interest of researchers and farmers as a viable option for food security. In spite of enormous benefit (Tangible and Intangible) provide by Agroforestry to society, its adoption at large scale in country face several challenges. This paper explains the potential of Agroforestry for providing diversified benefit for livelihood as well as in climate mitigation. The objective of this paper is to accumulate the traditional and current knowledge and standardized important research on Agroforestry potential's for food security and climate resilience.

\section{Agroforestry in India}

It is an age-old land use system, coexist with human evolution from forest. The practices of agroforestry are prevalent in variety of shape from ancient time in the country. There was many historical evidence which reflect the practices of Agroforestry an age old in India, like shifting cultivation (Vedic Era), trees on or in garden (Epic Era) and trees on farm boundary (Medieval periods). However in ancient time, many of these practices are not systematic but existed woody perennials with agriculture crop and or livestock. In the recent past Throughout India, Agroforestry systems come in a wide variety of shapes and forms. Tree or shrubs present on the farms either 
individually or in the form of line or woodlot or some time tree found randomly scattered in/on farms which reveal that there was forest present before establishment of agriculture. Depending on the environmental and sociocultural condition of the locality, they occupy, different types of Agroforestry systems have occurred in different places. Some prominent examples that illustrate the diversity of Agroforestry are the Shifting cultivation system of the North east, multistory home gardens of Kerala and Tamil Nadu, Taungya system of Uttar Pradesh. The system of Agroforestry literary were defined by P.K.R Nair in Indian condition however, some of these systems are traditional found in country (Pathak et al., 2000). An Agroforestry practices in turn denotes a distinctive arrangement of components in space and time (Nair, 1993). The major Agroforestry systems/practices found/identified in different regions of India according to suitability of climatic conditions of a locality are mentioned in table 2 .

Several Agroforestry practices are prevalent across the country according to specific relevance of site condition, climatic condition and socio-cultural needs of inhabitant societies of a region. These Agroforestry practices might be in different form but fulfill the same function of livelihood and environmental stability. There is thus no single classification scheme that can be universally applied (Torquebiau, 2000). What differentiates Agroforestry from other land uses is the deliberate inclusion of woody perennials on farms, which usually leads to significant economic and/ or ecological interactions between woody and non-woody system components (Nair, 1993). In most documented cases of successful Agroforestry establishment, tree-based systems are more productive, more sustainable and more attuned to people's cultural or material needs than treeless alternatives (Mbow et al., 2014). Yet Agroforestry practices are not being adopted across the country due to farmer's perception about tree component, marketing problems of produce, gap in research and extension activities and confusing policies of government. So, better foresight is required for productive and environmental performance of Agroforestry. The solution of these various factor and constraint make targeting indicators for Agroforestry intervention and key priority in Agroforestry research at world level.

\section{Agroforestry's contribution to food security and climate variability}

The systematic research on Agroforestry practices reveal that the particular land used system has diversified in nature specially, in relation to its product and environmental services. The role of Agroforestry in reference to livelihood of societies (Food production, employment generation) and climate resilience $(\mathrm{C}$ sequestration, soil conservation and water conservation) are noticeable. The current study used two framework, framework 1 assess the supporting role of Agroforestry in improving livelihood and climate resilience and framework 2 explain the services/opportunities provide by Agroforestry practices to societies.

Evaluation framework for assessing the supporting role of agroforestry in improving livelihood and climate resilience

Based on many years research on Agroforestry practices in different parts of India with various localities, we have found that all well managed Agroforestry practices are in fashion where land holding are marginal or small. Therefore Agroforestry technologies are more reliable and accepted to small scale farmers where expectation of commercial advantage are neglected or very low but the day to day needs with low capital and energy requirements are fulfilled very easily by this land use system. We challenged 
that indicators of the likely livelihood and climate resilience can be devolved based on Agroforestry option and that these indicators will be useful for reimburse the current and future variability of climate and food security. The indicators are related to the assessment of framework shown in figure 1.

The framework has five variables and each variables are complex and under influence through socio-culture aspect like farmer's perception, land availability, land tenure, labor, marketability of products, site condition and climatic condition of region.

But it is suggested that it is possible to develop this framework and buildup the indicator that will be practically useful for adaptation of these eco-friendly sustainable land use system.

\section{Variable I}

Agroforestry opportunities serve multifunctional and sustainable resources for livelihood and climate resilience. But some time Agroforestry opportunities show decline trend due to socio-culture aspect like farmer's perception, land availability, land tenure, labor, marketability of products, site condition and climatic condition of region and this will produce negative impact on the livelihood and climate resilience.

\section{Variable II}

Ecosystem services provided by Agroforestry include carbon sequestration, improvement of soil fertility and recycling of water. Agroforestry systems are promising land use system to increase and conserve aboveground and soil $\mathrm{C}$ stocks to mitigate climate changes (Dhyani et al., 2009).

Declining of these intangible services produce dreadful impact on society through climatic instability.

\section{Variable III}

Climate stability is outcome of ecosystem services. Agroforestry encourage the synergies between food security and climate change because tree component in Agroforestry are cost-effective and ecofriendly means of climate mitigation. Tree reduces the soil erosion and increases the fertility of soil by adding organic manure which provide a base for crop production. If there is instability in climate, due to degradation or deforestation, it hampers the crop production hence the survival ship of humankind jeopardizes.

\section{Variable IV}

Agriculture production and environment interlinked with each other. The biodiversity or environment is the feed stock for a climate resilient agriculture (Swaminathan, 1983 and Dhyani et al., 2005). Agriculture of India fully depends on man soon pattern but due to variability there is uncertainty in rainfall which affect the crop production in large way. So there is necessity to adopt sustainable multiple land use system (Agroforestry). Declining in agriculture production leads to negative impact on livelihood of humankinds.

\section{Variable V}

The role of Agroforestry opportunities are well defined in food security and poverty reduction. Agroforestry systems have diverse alternative and products which provide ample opportunities for employment generation and eliminate the poverty. If people consider both tangible and intangible benefits of Agroforestry, it will serve long term benefit to society not only at present but in future also. The potential of Agroforestry for rural development and employment generation is to the tune of 5.763 million human days per year from Indian Himalayas alone (Dhyani et al., 2005). 
This sustainable system of cropping is the only mean of food security in current climatic conditions of country or across the world. The insecurity of food and raise in poverty lead negative effect on livelihood and healthy environment.

Combining effect of forestry and agriculture practices in the form of Agroforestry on the society and environment

Agroforestry formed as an interface between agriculture and forestry in response to the particular needs and specific conditions of developing countries. The systemic researches in the field of Agroforestry show that these systems of land use have diversified benefit to society in several ways. By combining these intimate resources of nature, Agroforestry provide ample services to society either directly or indirectly. An Agroforestry service has enormous impact on society and environment. in terms of social benefit, it provide fuel, food, fodder and employment opportunities to societies simultaneously, it supply ecosystem services like carbon sequestration, water recycling and prevent soil, air and water from pollution. In fact the Agroforestry practices form one of the ways to achieve the goal of $33 \%$ of forest cover of country. Many researcher across the world found that reducing deforestation and forest degradation would be one of the cost effective and eco-friendly means of climate mitigation approach (Stern, 2006). These all attributes of Agroforestry, ultimately contribute into achieving the goal of biodiversity conservation through integrated conservation development approach. The opportunity provide by Agroforestry (combination of agriculture and forestry) to society for sustainable livelihood shown in figure 2. The framework show the combining effect of forestry, agriculture and or livestock on the society which would be benefited either directly or in the form of ecosystem services provided by Agroforestry.

Table.1 Carbon sequestrations through different form of vegetation

\begin{tabular}{|l|l|l|l|l|}
\hline S.N. & Plant species & Habit & $\begin{array}{l}\text { Carbon sequestration } \\
\left(\mathbf{M g ~ C ~} \mathbf{h a}^{-\mathbf{1}} \mathbf{\mathbf { y r } ^ { - 1 } \mathbf { ) }}\right.\end{array}$ & Reference \\
\hline 1. & $\begin{array}{l}\text { Phyllostachys } \\
\text { bambusoides }\end{array}$ & $\mathrm{B}$ & 52.3 & Isagiet al.,(1997) \\
\hline 2. & D. strictus & $\mathrm{B}$ & $91.35-103.70$ & Singh et al., (2004) \\
\hline 3. & B. bamboos & $\mathrm{B}$ & $83.3-103.8$ & $\begin{array}{l}\text { Das and Chaturvedi } \\
(2006)\end{array}$ \\
\hline 4. & A. auriculiformis & $\mathrm{T}$ & 19.38 & Shin et al., (2007) \\
\hline 5. & $\begin{array}{l}\text { Dipterocarpus } \\
\text { turbinatus }\end{array}$ & $\mathrm{T}$ & 18.98 & Shin et al., (2007) \\
\hline 6. & Swietenia mahagoni & $\mathrm{T}$ & 28.81 & Shin et al.,(2007) \\
\hline 7. & Populus deltoides & $\mathrm{T}$ & $8 \mathrm{Mg}$ & Kaulet al.,(2015) \\
\hline 8. & $\begin{array}{l}\text { Eucalyptus } \\
\text { terticornis }\end{array}$ & $\mathrm{T}$ & 98.27 & Devi et al.,(2013) \\
\hline 9. & Tectona grandis & $\mathrm{T}$ & 120.2 & Kraenzelet al.,(2003) \\
\hline 10. & Shorea robusta & $\mathrm{T}$ & $1 \mathrm{Mg}$ & Kaulet al.,(2015) \\
\hline 11. & Alnus nepalensis & $\mathrm{T}$ & 30.20 & Ranabhatet al.,(2008) \\
\hline
\end{tabular}

$\mathrm{T}=$ Tree, $\mathrm{B}=$ Bamboo. 
Table.2 Prominent agroforestry systems identified in different regions of India

\begin{tabular}{|c|c|c|c|c|}
\hline S.N & $\begin{array}{l}\text { Types of } \\
\text { Agroforestry } \\
\text { practices }\end{array}$ & Combinations & $\begin{array}{l}\text { Agro-ecological } \\
\text { Regions of country }\end{array}$ & Reference \\
\hline 1. & $\begin{array}{l}\text { Traditional } \\
\text { /Shifting } \\
\text { cultivation }\end{array}$ & $\begin{array}{l}\text { A patch of forest cleared and burn } \\
\text { then Grain crops are grown on } \\
\text { those blank patches for some years } \\
\text { after this the same patch will leave } \\
\text { fallow for regeneration of } \\
\text { vegetation. }\end{array}$ & $\begin{array}{lrr}\text { Mainly } & \text { North } & \text { east } \\
\text { states and } & \text { Tribe's } \\
\text { supported areas. } & \end{array}$ & $\begin{array}{l}\text { Garbyal, } \\
\text { (1999) }\end{array}$ \\
\hline 2. & Taungya & $\begin{array}{l}\text { Woody plant+ Arable crops. } \\
\text { Main purpose to reduce weed } \\
\text { growth in early stage of plantation } \\
\text { (Departmental Taungya), for } \\
\text { sustainable livelihood and income } \\
\text { generation (In village Taungya and } \\
\text { Leased based Taungya). }\end{array}$ & $\begin{array}{l}\text { In all regions but in } \\
\text { large scale in U.P., } \\
\text { U.K., Cachar regions of } \\
\text { Assam and hilly areas } \\
\text { where land holding is } \\
\text { very minute in quantity. }\end{array}$ & $\begin{array}{l}\text { Rowbotham, } \\
\text { (1924) }\end{array}$ \\
\hline 3. & $\begin{array}{l}\text { Trees scattered } \\
\text { outside or inside } \\
\text { the farm. }\end{array}$ & $\begin{array}{l}\text { MPTs trees scattered on farm } \\
\text { either in the form of wind break, } \\
\text { shelter belt or scattered in the field. }\end{array}$ & $\begin{array}{l}\text { All regions especially } \\
\text { specially on the field of } \\
\text { small and marginal } \\
\text { farmers. }\end{array}$ & Tewari, (2008) \\
\hline \multirow[t]{5}{*}{4.} & \multirow[t]{5}{*}{$\begin{array}{l}\text { Plantation or } \\
\text { cash crop based } \\
\text { Agroforestry } \\
\text { systems }\end{array}$} & $\begin{array}{l}\text { (A) Mixing of tree with different } \\
\text { strata with plantation crops. }\end{array}$ & $\begin{array}{l}\text { Plantations like coffee } \\
+\quad \text { fruit trees/ } \\
\text { ornamental tree }+ \\
\text { spices/ vegetables } \\
\text { in humid and sub- } \\
\text { humid tropical regions }\end{array}$ & Dagar, (2014) \\
\hline & & (ii) Plantation crops+ Shade tree & $\begin{array}{l}\text { Tea plantations + shade } \\
\text { trees North East }\end{array}$ & \\
\hline & & $\begin{array}{l}\text { (iii) Fast growing tree species of } \\
\text { industrial value+ Field crop }\end{array}$ & $\begin{array}{l}\text { Punjab, Haryana, U.P } \\
\text { etc. }\end{array}$ & $\begin{array}{l}\text { Chauhan et al., } \\
\text { (2012) }\end{array}$ \\
\hline & & (iv) Fruit Tree + Grass land & $\begin{array}{l}\text { Very high slope where } \\
\text { arable crop cannot } \\
\text { grow. }\end{array}$ & Singh (2008) \\
\hline & & (v) Coconut based mix farming. & $\begin{array}{lll}\begin{array}{l}\text { Coastal region } \\
\text { country }\end{array} & & \\
\end{array}$ & $\begin{array}{l}\text { Dagar }(1991, \\
1995 \text { and } 2000)\end{array}$ \\
\hline 5. & Inter cropping & $\mathrm{N}_{2}$ fixing trees+ Crops/Grasses & $\begin{array}{l}\text { All region of the } \\
\text { country }\end{array}$ & \\
\hline 6. & Home gardens & $\begin{array}{l}\text { Multi-storey combination of MPTs } \\
\text { with vegetable spices, fruit tree in } \\
\text { multiple strata }\end{array}$ & $\begin{array}{l}\text { Mainly in Southern part } \\
\text { of country where rain } \\
\text { fall is above } 2500 \mathrm{~mm}\end{array}$ & Kumar (2010) \\
\hline 7. & Silvo-Pasture & Trees + Grasses & $\begin{array}{l}\text { Hills and dry region } \\
\text { where rainfall is scanty } \\
\text { on soil depth is very } \\
\text { less. }\end{array}$ & Singh (2008) \\
\hline 8. & $\begin{array}{l}\text { Shelter belts or } \\
\text { wind } \\
\text { Breaks of either } \\
\text { tree or shrubs }\end{array}$ & $\begin{array}{l}\text { Crops are grow on leeward side of } \\
\text { tree component to reduce the wind } \\
\text { speed }\end{array}$ & $\begin{array}{l}\text { In all regions but } \\
\text { mainly where wind } \\
\text { speed is very high and } \\
\text { soil erosion marked like }\end{array}$ & Dagar (2014) \\
\hline
\end{tabular}




\begin{tabular}{|c|c|c|c|c|}
\hline & and herbs & & Rajasthan. & \\
\hline 9. & $\begin{array}{lr}\text { Cut and } & \text { carry } \\
\text { systems } & \\
\text { improved } & \text { form } \\
\text { of silvo-pasture } \\
\text { system also } \\
\text { called protein } \\
\text { banks }\end{array}$ & $\begin{array}{l}\text { Leguminous tree are grown along } \\
\text { with grass land. Example- Acacia } \\
\text { nilotica+Grasses (highly palatable) }\end{array}$ & $\begin{array}{l}\text { Research farm, dry and } \\
\text { waste land }\end{array}$ & $\begin{array}{l}\text { Mathukia et al., } \\
\text { (2016) }\end{array}$ \\
\hline 10. & $\begin{array}{l}\text { Wadi form of } \\
\text { cultivation }\end{array}$ & $\begin{array}{l}\text { Arable crop are grown with } \\
\text { intercropping of fruit tree inside } \\
\text { the field and forestry tree species } \\
\text { are grown on the boundary of field }\end{array}$ & $\begin{array}{l}\text { Practices are carried out } \\
\text { in Gujarat, M.H, } \\
\text { Karnataka and some } \\
\text { parts of Rajasthan with } \\
\text { the help of BAIF. }\end{array}$ & Hegde (2005) \\
\hline 11. & $\begin{array}{l}\text { Agri-silvi- } \\
\text { apicuture }\end{array}$ & $\begin{array}{l}\text { Agriculture crop(mainly mustard) } \\
+ \text { Tree }+ \text { Honey bee rearing }\end{array}$ & $\begin{array}{l}\text { Punjab, Haryana, Parts } \\
\text { of M.P., Rajasthan etc. }\end{array}$ & $\begin{array}{l}\text { Gill et al., } \\
(2010)\end{array}$ \\
\hline 12. & Others & $\begin{array}{l}\text { Aqua agroforestry (Acacia } \\
\text { nilotica, Syzygium cuminii grow on } \\
\text { the boundary of fish pond). }\end{array}$ & $\begin{array}{l}\text { Followed in many } \\
\text { places in N.E states like } \\
\text { Assam and Bastar } \\
\text { region of C.G }\end{array}$ & $\begin{array}{l}\text { Chavan et al., } \\
\text { (2015) }\end{array}$ \\
\hline
\end{tabular}

Table.3 Tree species highly boost up the nutrient status of soil

\begin{tabular}{|c|c|c|c|c|c|c|}
\hline \multirow[t]{2}{*}{ S.N } & \multirow[t]{2}{*}{ Plant species } & \multicolumn{3}{|c|}{$\begin{array}{l}\text { Nutrient contents } \\
\left(\mathrm{Kg} \mathrm{ha}^{-1}\right)\end{array}$} & \multirow[t]{2}{*}{ Remark } & \multirow[t]{2}{*}{ Reference } \\
\hline & & $\mathrm{N}$ & $\mathrm{P}$ & $\mathrm{K}$ & & \\
\hline 1. & $\begin{array}{l}\text { Prosopis } \\
\text { juliflora }\end{array}$ & 231 & 7 & 333 & Whole tree & $\begin{array}{l}\text { Tewari et al., (2014); } \\
\text { Dagar } \text { et al., (2014) }\end{array}$ \\
\hline 2. & $\begin{array}{l}\text { Prosopis } \\
\text { cineraria }\end{array}$ & 221 & 11 & 479 & Whole tree & $\begin{array}{l}\text { Tewari et al., (2014); } \\
\text { Dagar et al., (2014) }\end{array}$ \\
\hline 3. & $\begin{array}{l}\text { Gliricidia } \\
\text { sepium }\end{array}$ & 21 & 2.5 & 18 & 1 tone leaf/ha & Rao et al., (2011) \\
\hline 4. & Albizia stipulata & 458 & 39 & 437 & $\begin{array}{l}20 \text { years old } \\
\text { plantation }\end{array}$ & UHF (2010) \\
\hline 5. & $\begin{array}{l}\text { Dalbergia } \\
\text { sissoo }\end{array}$ & 459 & 32 & 409 & $\begin{array}{l}20 \text { years } \text { old } \\
\text { plantation }\end{array}$ & UHF (2010) \\
\hline 6. & $\begin{array}{l}\text { Terminalia } \\
\text { arjuna }\end{array}$ & 275 & 28 & 388 & $\begin{array}{l}20 \text { years old } \\
\text { plantation }\end{array}$ & UHF (2010) \\
\hline 7. & $\begin{array}{l}\text { Sesbania } \\
\text { aculeata }\end{array}$ & 1.5 & 0.3 & 2.0 & $\begin{array}{l}\text { Percentage } \\
\text { nutrient content of } \\
\text { green foliage }\end{array}$ & $\begin{array}{l}\text { Khadka et al., (1987), } \\
\text { Sthapit and Subedi } \\
\text { (1989) }\end{array}$ \\
\hline 8. & $\begin{array}{l}\text { Pongamia } \\
\text { pinnata }\end{array}$ & 3.69 & 2.41 & 2.42 & $\begin{array}{l}\text { Percentage } \\
\text { nutrient content of } \\
\text { green foliage }\end{array}$ & Patnaik, (1987) \\
\hline 9. & Madhuca indica & 1.66 & 0.50 & 2 & $\begin{array}{l}\text { Percentage } \\
\text { nutrient content of } \\
\text { green foliage }\end{array}$ & Patnaik, (1987) \\
\hline
\end{tabular}


Table.4 Role of Agroforestry (different crop combination), Forestry and Agriculture in water conservation

\begin{tabular}{|l|l|l|l|}
\hline S.N & Cropping systems & $\begin{array}{l}\text { Water } \\
\text { efficiency } \\
(\mathbf{K g} / \mathbf{h a} / \mathbf{c m})\end{array}$ & use \\
\hline 1. & Acacia saligna + Sorghum & 159 & Droppelmonnet al., (2000) \\
\hline 2. & Acacia saligna + Cow pea & 121 & Droppelmonnet al., (2000) \\
\hline 3. & Eucalyptus spp. + Rice & 675 & Wongpromet al., (2010) \\
\hline 4. & $\begin{array}{l}\text { Eucalyptus spp. plantation } \\
\text { (Exotic) }\end{array}$ & 93 & Zahid et al., (2007) \\
\hline 5. & $\begin{array}{l}\text { Dalbergiasissoo plantation } \\
\text { (Indigenous) }\end{array}$ & 89 & Zahid et al., (2007) \\
\hline 6. & Wheat & 104.9 & Yan et al., (2014) \\
\hline 7. & Rice & 43 & Ganiyuet al.,(2012) \\
\hline 8. & Cotton & 23 & Singh et al., (2006) \\
\hline
\end{tabular}

Fig.1 Evaluation framework for assessing the supporting role of Agroforestry in improving livelihood and climate resilience

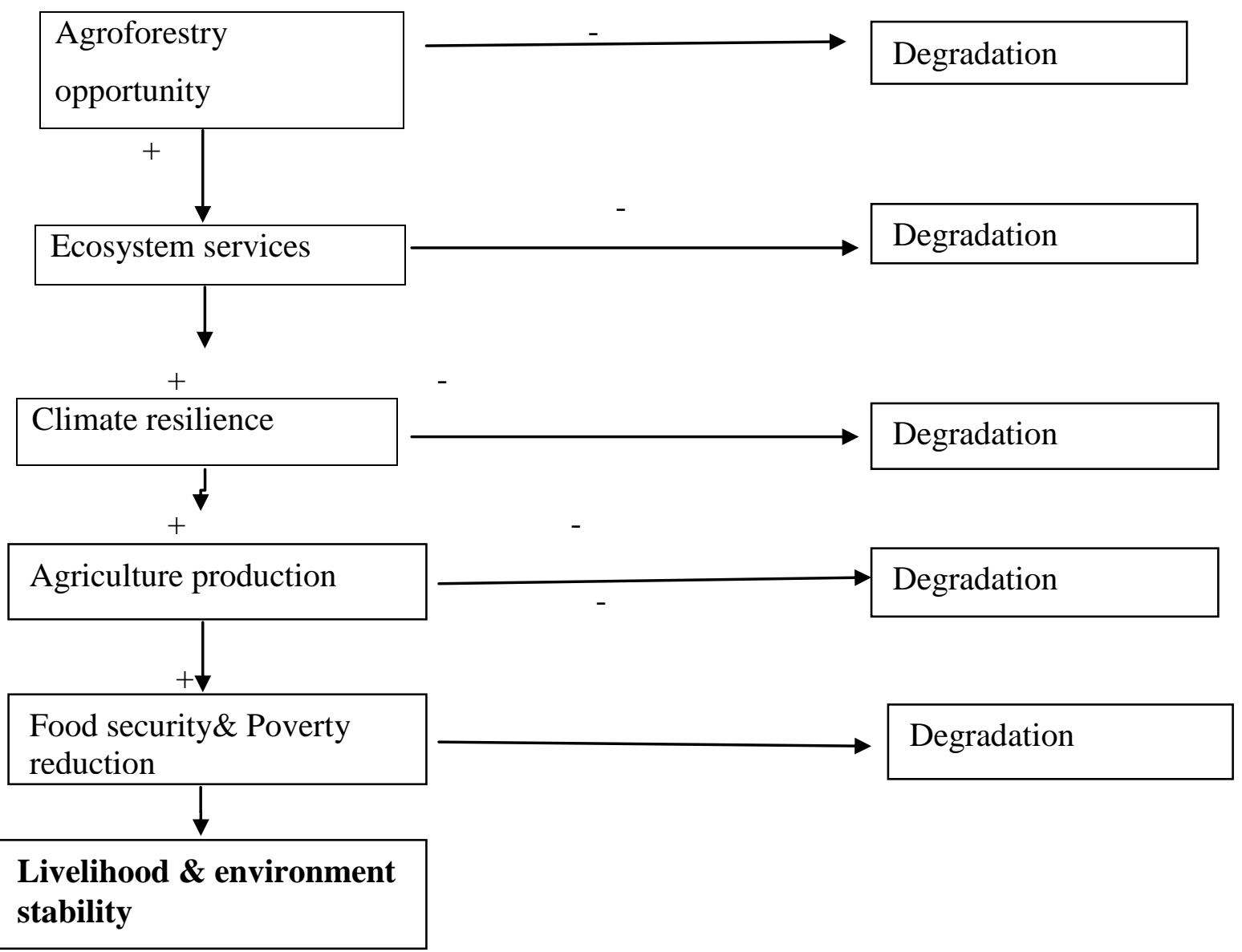

Note: + stand positive impact of indicators and - stand for decreasing or negative impact of indicators on livelihood and environment stability. 
Fig.2 Framework for agroforestry opportunities

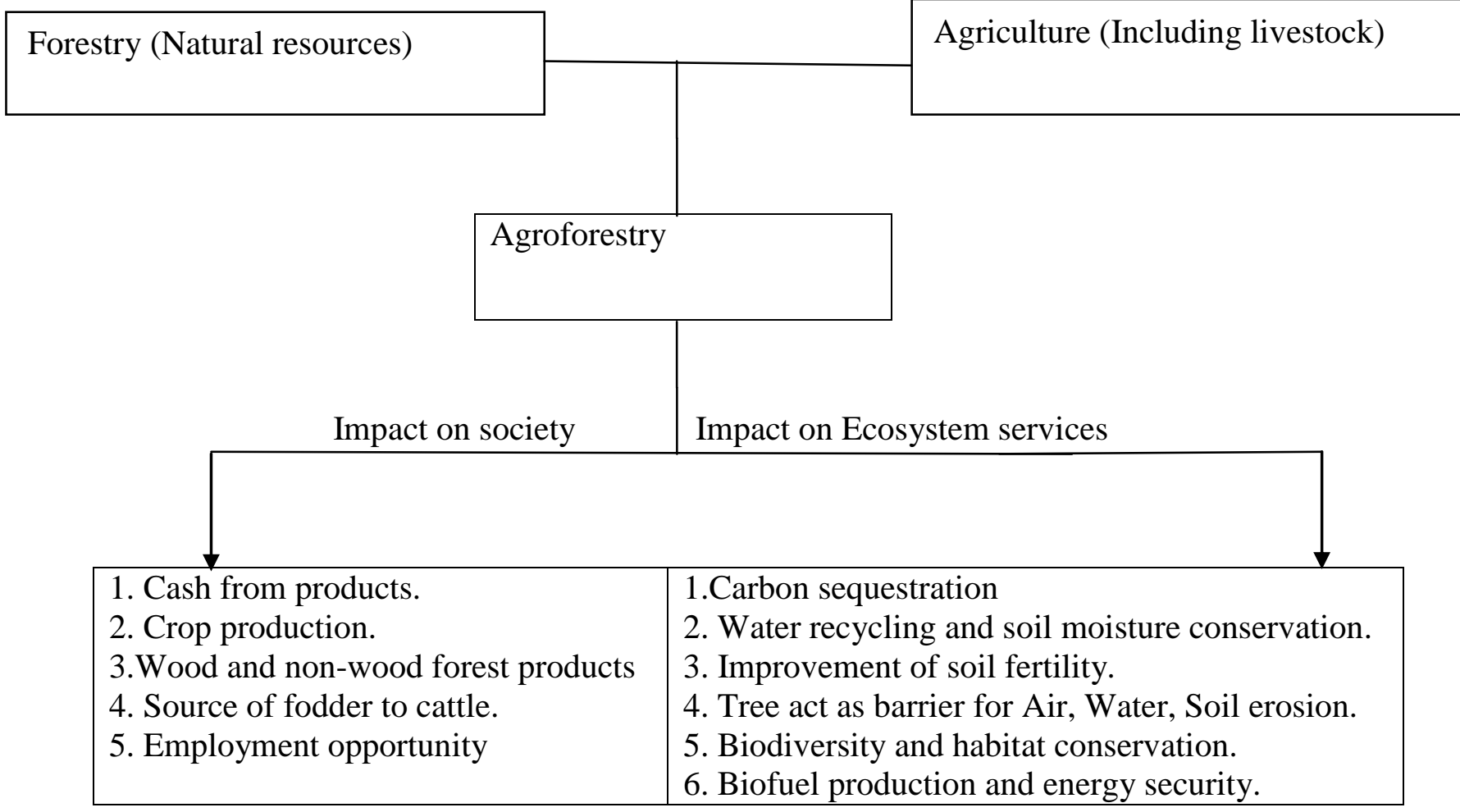

Now a day's the level of $\mathrm{CO}_{2}$, greenhouse gases in atmosphere has increased from a certain limit, which cause drastic change in the atmosphere, land and also in hydrosphere. Forest or tree is the only a sustainable biological mean to combat these alarming situation of the globe. The tree, herb and shrub are an essential part of Agroforestry practices of cultivation, every tree, herb, shrubs have a specific uniqueness regarding the carbon sequestration which are shown in table 1 .

Agroforestry improve the soil fertility by adding organic manures through litter fall, degradation of tree branches, twigs and woody components. Tree components are source of essential macro, micro nutrients and also play significant role in nutrient recycling, Tree draw the nutrients from deeper layer of soil and make accessible to crops. Every tree have source of nutrients, some are shown in table 3 .
The contribution of Agroforestry in water conservation is highly marked. The tree component in Agroforestry play important role in water recycling and conservation of soil moisture by reducing runoff and rain intensity. Agroforestry has potential for improving water use efficiency by reducing the unproductive components of the water balance, i.e. run-off, soil evaporation and drainage (Ong et al., 2002).

There are several studies carried out across the world which show the enormous contribution of Agroforestry in water conservation than mono-cropping (Agriculture and Forestry). There are different forms of Agroforestry practiced across the world. The tree component and crop component of Agroforestry varied according to locality and needs of human population of particular region. The different forms of Agroforestry demonstration is the different trends of water conservation. 
The contribution of Agroforestry in water conservation is depicted in table 4 .

\section{Recent trends in agroforestry in India}

As we stated already the practices of Agroforestry is not new to the farmers of India. The farmers of India practices Agroforestry traditionally from time immemorial. But in recent past the population of country increase many fold and the availability of land for particular family decrease simultaneously due to this the people more focus on the food production than other activities. To compensate these alarming situation a need will come to forward to concerned the research and extension on the Agroforestry. Because the scientific techniques and research on Agroforestry aspects proof the high yield and diversified products on small and marginal land. The new innovation and scientific approaches in the field of agrforestry proof it highly beneficial and climate mitigating cultivation system across the world. The research and extension activities in field of agroforestry are not only limited to government organization but there are many Other than Govt. organizations like NGOs, private firms also involved in the field of Agroforestry. BAIF, ITC developed several clones of Eucalyptus, poplar which are fast growing, multiple uses and source of early return to farmers. BAIF start a programme on Agroforestry "WADI" in several states. WADI system accepted in several states like, Maharashtra, Karnataka, Andhra Pradesh etc. at large scale due to its simplicity and multiple benefits to farmers.

In conclusion, Agroforestry is a diversified, eco-friendly and sustainable land use system. In Indian region Agroforestry has wide scope and ample opportunity. Our country is on growing phase in each and every aspect of developments. The population of country increased many fold in recent past, the industrialization phase of country also not yet complete and the construction activates all are in progress. All these factors are putting extra burden on the limited availability of cultivated land and natural resources of country which accomplish with arise of food problem and climate changes. There are several parts in country which face several problems like, floods, drought, waste land, steep slopes, these situations of a region makes it unsuitable for crop cultivation. In this situation Agroforestry only the means of rehabilitation of these degraded lands and problems. The tree components in Agroforestry contribute several direct and indirect benefits to humankind. There are several tree species that have vast multiple uses and early return are untouched or little exposure in this field like munga, mulberry etc. can introduce on farmer fields. So it is concluded that an increasing phase of development and decline situations of natural resources, Agroforestry can only fit to resolve the problems of food availability and climate change due to its diversify, eco-friendly nature and multiple benefits.

\section{References}

Chavan, S. B., Keerthika, A., Dhyani, S. K., Handa, A. K., Ram Newaj and Rajarajan, K. (2015). National agroforestry policy in India: a low hanging fruit. Current Science, 108(10): 1826-1834.

Dagar, J. C., Singh, A. K. and Arunachalam, A. (2014). Agroforestry systems in India: Livelihood security and ecosystem services. Advance in agroforestry, 2014, vol. 10.

Das, D. K., Chaturvedi, O.P. (2006). Bambusa bambos (L.) Voss plantation in eastern India: I. Culm recruitment, dry matter dynamics and carbon flux. Journal of Bamboo and Rattan 5: 47-59.

Das, D., Chaturvedi, O.P. (2008). Root biomass and distribution of five agroforestry tree 
species, Agroforestry Systems, 2008, 74(3): 223-230.

DeFries, R., Rosenzweig, C. (2010). Toward a whole-landscape approach for sustainable land use in the tropics, Proceedings of the National Academy of Sciences, 2010, 107(46): 19627-19632.

Devi, B., Bhardwaj, D.R., Panwar, P., Pal, S., Gupta, N.K., Thakur, C.L. (2013). Carbon allocation, sequestration and carbon dioxide mitigation under plantation forests of north western Himalaya, India. Ann for Res 56(1): 123-135.

Dhyani, S. K., Kumar, R. V., Ahlawat, S. P. (2011). Jatropha curcas L,: A potential biodiesel crop and its current RandD status. Indian J Agric Sci, 2011, 81(4):295-308

Dhyani, S. K., Ram, N. and Sharma, A. R. (2009). Agroforestry: its relation with agronomy, challenges and opportunities. Indian J. Agron 2009, 54(3):70-87

Dhyani, S. K., Sharda, V. N. and Samara, J. S. (2005). Agroforestry for sustainable management of soil, water and environmental quality; looking back to think ahead. Range Manag Agrofor, 26(1):71-83

Dhyani, S.K., Sharda, V.N. (2005). Agroforestry systems as rural development options for the Indian Himalayas. J Tree Sci 24(1):1-19

Droppelmann, K.J., Lehmann, J., Ephrath, J.E., Berliner, P.R. (2000). Water use efficiency and uptake patterns in a runoff agroforestry system in an arid environment. Agroforestry Systems 49(3): 223-243.

Ganiyu, S., Amanatu, M.K., Korese, J.K. (2012). Water use efficiency and productivity for rice (oryza sativa) in the Bontanga irrigation scheme of northern region of Ghana. Agricultural Science Research Journals 2(7): 362-368.

Garbyal, S.S.(1999). Jhuming (Shifting cultivation) in Mizoram (India) and new land use policy- how far it has succeeded in containing this primitive agriculture practice'. Indian Forester, 125, 137-148.

Gill, R.I.S., Singh, B., Kaur, N., Sangha, K.S. (2010). Agroforestry - A viable option for crop diversification in Punjab. Department of Forests and Wildlife Preservation Punjab. pp. 20.

Haile, S. G., Nair, P. K. R., and Nair, V. D. (2008). Carbon storage of different soilsize fractions in Florida silvopastoral systems. Journal of environmental quality, 2008, 37(5), 1789-1797.

Hegde, N.G. (2005). Tree based Farming for Sustainable Livelihood at the workshop on Tropical Forestry and Poverty Eradication, Bangkok, Thailand. Apr. 56.

Isagi, Y., Kawahara, T., Kamo, K., Lto, H. (1997). Net production and carbon cycling in bamboo Phyllostachys pubescens stand. Plant Ecology 130: 4152.

Kareemulla, K., Rhizvi, R.H., Yadav, R.S., Munna, R., Dhyani, S.K. (2009). Agroforestry for rural developmentcooperatives as viable institutions. Agriculture situation in India, 2009. pp 61-67

Kaul, M., Mohren, G. M. J., Dadhwal, V. K. (2010). Carbon storage and sequestration potential of selected tree species in India. Mitig Adapt Strateg Glob Change, 15:489-510

Khadka, R.J., Chand S.P. (1987). The organic materials. A valuable source of soil nutrient in the eastern hills of Nepal. PAC working paper 12/87. Pakhribar agricultural centre, Dhankuta, Nepal.

Kraenzel, M.B., Moore, T., Castillo, A., Potvin, C. (2003). Carbon storage of harvestageteak (Tectona grandis) plantations, Panama. Forest Ecol. Manage. 173, 213225.

Kumar, B.M. (2010) Species richness and aboveground carbon stocks in the home gardens of central Kerala, India. AgricEcosyst Environ 140:430-440

Mathukia, R.K., Sagarka, B.K., Panara, D.M. (2016). fodder production through 
agroforestry: a boon for profitable dairy farming. Innovare Journal Of Agri. Sci, Vol 4, Issue 2, 13-19

Mbow, C., Noordwijk, M. V., Luedeling, E., Neufeldt, H., Minang, P. A. and Kowero, G. (2014). Agroforestry solutions to address food security and climate change challenges in Africa. Current Opinion in Environmental Sustainability 2014, 6:61-67

Nair, P. K. R., Kumar, B. M., and Nair, V. D. (2009). Agroforestry as a strategy for carbon sequestration. Journal of plant nutrition and soil science, 2009, 172(1), 10-23.

Nair, P.K.R. An introduction to agroforestry. Kluwer Academic Publishers, The Netherlands 1993.

NRCAF Jhansi, the success stories of National Research Centre for Agroforestry, 12-62011.

Ong, C.K., Wilson, J., Deans, J.D., Mulayta, J., Raussen, T., Wajjamusukwe, N. (2002). Tree-crop interactions: Manipulation of water use and root function. Agricultural Water Management 53(1-3): 171-186.

Palm, C., Tomich, T., Van Noordwijk, M., Vosti, S., Gockowski, J., Alegre, J., and Verchot, L. (2004). Mitigating GHG emissions in the humid tropics: case studies from the Alternatives to Slashand-Burn Program (ASB). Environment, Development and Sustainability, 2004, 6(1-2), 145-162.

Pandey, D. N. (2007). Multifunctional agroforestry systems in India, Current Science, 2007, 92(4): 455-463.

Pathak, P. S. and Dagar, J. C. (2000). Traditional agroforestry sytems: an overview. In: Soni $\mathrm{P}$, Srivastava AK (eds) Landmarks of botany in India. Suriya International Pub., Dehradun 2000, pp 26-49

Patnaik, N. (1987). Soil fertility and fertilizer use. In: Handbook of Agriculture, ICAR, New Delhi, pp 213-230.

Ranabhat, S., Awasthi, K.D., Malla, R. (2008). Carbon sequestration potential of Alnus nepalensis in the mid hill of Nepal: a case study from Kaski district. BankoJanakari 18(2):3-9

Rao, S., Venkateswaralu, B., Dinesh Babu, M., Wani, S.P., Dixit, S., Sahrawat, K.L., Kundu, S. (2011). Soil health improvement with Gliricidia green leaf manuring in rainfed agriculture, On Farm Experiences. Central Research Institute of Dryland Agriculture, Santoshnagar, $p$ 16. ICRISAT, Technical Bulletin No.2/2011, A.P. India.

Sahu, M. L., Kumar, Y. (2015). Exploring rainwater harvesting potential of Terminalia belerica Roxb. Through rainfall partitioning and soil infiltration study. Journal of tropical forestry, 2015, Vol.31 (3): 1-7.

Shin, M.Y., Miah, M.D., Lee, K. (2007). Potential contribution of the forestry sector in Bangladesh to carbon sequestration. J. Environ. Manag. 82, 260-276.

Singh, K.A. (2008). Resource management perspective for forage production and agroforestry system development in eastern Himalayan region: A review. Indian journal of Agronomy, Vol 53, Issue 4, 255-266

Singh, P., Dubey, P., Jha, K.K. (2004). Biomass production and carbon storage at harvest age in superior Dendrocalamus strictus plantation in dry deciduous forest region in India. pp. 35. In: H. P. Singh and N. K. Dadlani (eds.) Abstract Volume of VIIth World Bamboo Congress, 27th February - 4th March, New Delhi, India.

Stern, N. Review on the economics of climate change. HM Treasury, London 2006.

Sthapit, B.R. (1989). Comparative performance of indigenous green manuring species on yields of rice. LAC technical paper 23/89. Lumle agricultural centre, kaski, Nepal.

Subedi, K.D. (1989). The green manures. Prabidhisanglo, year, 3, Vol.4, 9-12. Publication in nepali. Lumle agricultural centre, kaski, Nepal.

Swaminathan, M.S. Genetic conservation: microbes to man. Presidential address to 
the 15th International Congress on Genetics. In: Genetics: new frontiers, 1983, Vol. 1. Oxford and IBH Publishing Co., New Delhi, India.

Tewari, J.C., Ram, M., Roy, M.M., Dagar, J.C. (2014). Livelihood Improvements and Climate Change Adaptations Through Agroforestry in Hot Arid Environments. Agroforestry systems in India: Livelihood security and ecosystem services. Advance in agroforestry, 2014, vol. 10.

Thenmozhi, S., Thilagavath, P. (2014). Impact of agriculture on Indian economy. International Research Journal of Agriculture and Rural Development. Vol.3, December 2014.

Tiwari, S.K. (2008). Agro-forestry Project; Dept. of Genetics and Plant Breeding College of Agriculture, G.B. Pant University of Agriculture and Technology Pantnagar - 263145. (14-12008)

Torquebiau, E. F. (2000). A renewed perspective on agroforestry concepts and classification. Comptes Remdus Academie des Sciences Paris, Sciences de la vie/Life Sciences 2000, 323:10091017.

UHF (2010) Annual research report (2009-10). Annual research reports submitted to All India Coordinated Research Project on Agroforestry, College of Forestry, Dr Y $S$ Parmar University of Horticulture and Forestry, Solan, p 62

Wongprom, J., Wachrinrat, C., Srigongpan, R., Jumwong, N., Klangsap, N. (2010).
Water use and water use efficiency of different spacing eucalypt planted on paddy bund at Phanom district, Chachoengsao province (Thai). Proceeding of the $48^{\text {th }}$ Kasetsart University Annual Conference, Kasetsart, 3-5 March, 2010. Subject: Natural Resources and Environment 2010 pp. unpaginated.

Yan $\mathrm{N}$ and $\mathrm{Wu}$ B. (2014). Integrated spatialtemporal analysis of crop water productivity of winter wheat in Hai Basin. Agricultural Water Management 133:24-33.

Zahid, D.M., Nawaz, A. (2007). Comparative Water Use Efficiency of Eucalyptus camaldulensis Versus Dalbergia sissoo in Pakistan Int. J. Agri. Biol., Vol. 9, No. 4, 2007

Chauhan, S.K., Sharma, R., Dhillon, W.S. (2012). Status of Intercropping in Poplar Based Agroforestry in India. Forestry Bulletin, 12(1),2012

Dagar, J.C. (2000). Agroforestry systems for coastal and island regions. Indian $\mathbf{J}$ Agrofor 2:59-74

Dagar, J.C. (1991). Agroforestry practices for coastal Bay Islands. J Indian Soc Coastal Agril Res 9:433-439

Dagar, J.C. (1995a) Agroforestry systems for Andaman and Nicobar Islands in India. Int tree Crops J 8(2and3):107-128

55. Rowbotham, C.J. (1924). The Taungya system in cachar division, Asam. The Indian forester, Vol. 50, Issue, 7, 1924

\section{How to cite this article:}

Yogesh Kumar and Tarun Kumar Thakur. 2017. Agroforestry: Viable and Futuristic Option for Food Security and Sustainability in India. Int.J.Curr.Microbiol.App.Sci. 6(7): 210-222. doi: https://doi.org/10.20546/ijcmas.2017.607.025 